\title{
Predictors for development of palbociclib-induced neutropenia in breast cancer patients as determined by ordered logistic regression analysis
}

Yuko Kanbayashi ( $\square$ kanbayashi@gly.oups.ac.jp )

Osaka Medical and Pharmaceutical University

Koichi Sakaguchi

Kyoto Prefectural University of Medicine

Takeshi Ishikawa

Kyoto Prefectural University of Medicine

Koichi Takayama

Kyoto Prefectural University of Medicine

Tetsuya Taguchi

Kyoto Prefectural University of Medicine

\section{Research Article}

Keywords: palbociclib, neutropenia, breast cancer, statins, body mass index

Posted Date: July 9th, 2021

DOI: https://doi.org/10.21203/rs.3.rs-679084/v1

License: (c) (1) This work is licensed under a Creative Commons Attribution 4.0 International License.

Read Full License 


\section{Abstract}

This retrospective study aimed to identify predictors for the development of palbociclib-induced neutropenia. This study retrospectively analysed 78 breast cancer patients who had received palbociclib at our hospital between January 2018 and May 2020. For the regression analysis of factors associated with palbociclib-induced neutropenia, variables were extracted manually from medical charts. The level of palbociclib-induced neutropenia was evaluated using the National Cancer Institute's Common Terminology Criteria for Adverse Events (version 5). Multivariate ordered logistic regression analysis was performed to identify predictors for the development of neutropenia. Optimal cut-off thresholds were determined using receiver operating characteristic (ROC) analysis. Values of $P<0.05$ (2-tailed) were considered significant. Significant factors identified included concomitant use of statin (odds ratio [OR] = $0.104,95 \%$ confidence interval $[\mathrm{Cl}]=0.018-0.598 ; P=0.011]$ and body mass index $(\mathrm{BMI})(\mathrm{OR}=1.118,95 \%$ $\mathrm{Cl}=1.007-1.241 ; P=0.037$ ). ROC analysis revealed that neutropenia (grade 4) was more likely to occur with a $\mathrm{BMI} \geq 22.3 \mathrm{~kg} / \mathrm{m}^{2}$. In conclusion, no concomitant use of statins and high BMI were identified as significant predictors for the development of palbociclib-induced neutropenia.

\section{Introduction}

Palbociclib plus endocrine therapy is the standard treatment for hormone receptor-positive, human epidermal growth factor receptor 2-negative metastatic breast cancer [1-9]. On the other hand, severe neutropenia has been reported as an adverse effect after palbociclib administration [6, 9]. Neutropenia is the dose-limiting toxicity associated with palbociclib. However, the development of neutropenia poses a risk of febrile neutropenia and is associated with shortened life prognosis due to dose reduction, leading to decreases in quality of life (QOL). This retrospective study was thus undertaken to identify predictors associated with the development of palbociclib-induced neutropenia to help guide future strategies toward improved safety, efficacy, and QOL in breast cancer patients treated using palbociclib.

\section{Results}

All 78 patients who received palbociclib were enrolled in this study. Table 1 presents the clinical characteristics of the 78 enrolled patients, the potential variables related to the development of neutropenia, and the results of univariate analyses. The forward stepwise selection procedure identified the following candidate variables: use of statins, use of proton pump inhibitors (PPIs), number of cycles, body mass index (BMI) and platelet count. Multivariate ordered logistic regression analysis was performed using these variables. Significant factors identified included concomitant use of statin (odds ratio $[\mathrm{OR}]=0.104,95 \%$ confidence interval $[\mathrm{Cl}]=0.018-0.598 ; P=0.011)$ and $\mathrm{BMI}(\mathrm{OR}=1.118,95 \% \mathrm{Cl}=$ 1.007-1.241; $P=0.037$ ) (Table 2). Receiver operating characteristic (ROC) analysis revealed that neutropenia (grade 4) was more likely to occur with $\mathrm{BMI} \geq 22.3 \mathrm{~kg} / \mathrm{m}^{2}$, with $71.0 \%$ sensitivity and $48.4 \%$ specificity (area under the curve $[\mathrm{AUC}]=0.54$ ). 
Table 1

Patient characteristics, extracted variables, and results of univariate analyses $(n=78)$

\begin{tabular}{|c|c|c|c|c|c|c|}
\hline & $\begin{array}{l}\text { Grade } 1 \\
(n=4)\end{array}$ & $\begin{array}{l}\text { Grade } 2 \\
(n=15)\end{array}$ & $\begin{array}{l}\text { Grade } 3 \\
(n=45)\end{array}$ & $\begin{array}{l}\text { Grade } 4 \\
(n=14)\end{array}$ & $\begin{array}{l}P \\
\text { value }\end{array}$ & $\begin{array}{l}\text { Odds } \\
\text { ratio } \\
(95 \% \mathrm{Cl})\end{array}$ \\
\hline \multicolumn{7}{|l|}{ Demographic data } \\
\hline \multirow[t]{2}{*}{$\operatorname{Age}(y)$, median (range) } & 73.5 & 60 & 61 & 59.5 & 0.710 & 0.99 \\
\hline & $\begin{array}{l}(58- \\
77)\end{array}$ & $(39-73)$ & $(40-83)$ & $\begin{array}{l}(46- \\
79)\end{array}$ & & $\begin{array}{l}(0.96- \\
1.03)\end{array}$ \\
\hline \multirow[t]{2}{*}{ Height (cm), median (range) } & 157 & 152 & 156 & 156 & 0.111 & 1.06 \\
\hline & $\begin{array}{l}(144- \\
161)\end{array}$ & $\begin{array}{l}(145- \\
68)\end{array}$ & $\begin{array}{l}(144- \\
167)\end{array}$ & $\begin{array}{l}(148- \\
165)\end{array}$ & & $\begin{array}{l}(0.99- \\
1.14)\end{array}$ \\
\hline \multirow[t]{2}{*}{ Weight (kg), median (range) } & 43.6 & 50 & 54 & 55.5 & 0.097 & 1.04 \\
\hline & $\begin{array}{l}(31.6- \\
62.0)\end{array}$ & $(40-67)$ & $(40-85)$ & $\begin{array}{l}(33.6- \\
78.9)\end{array}$ & & $\begin{array}{l}(0.99- \\
1.08)\end{array}$ \\
\hline \multirow[t]{2}{*}{$B M I\left(k g / m^{2}\right)$, median (range) } & 17.8 & 21.0 & 22.5 & 21.0 & 0.310 & 1.05 \\
\hline & $\begin{array}{l}(14.9- \\
23.9)\end{array}$ & $\begin{array}{l}(17.3- \\
29.7)\end{array}$ & $\begin{array}{l}(16.6- \\
35.8)\end{array}$ & $\begin{array}{l}(15.3- \\
34.9)\end{array}$ & & $\begin{array}{l}(0.95- \\
1.16)\end{array}$ \\
\hline \multirow[t]{2}{*}{$P S(0 / 1 / 2 / 3)$} & $3 / 0 / 1 / 0$ & $9 / 5 / 1 / 0$ & $23 / 19 / 3 / 0$ & $8 / 4 / 1 / 1$ & 0.452 & 1.27 \\
\hline & & & & & & $\begin{array}{l}(0.68- \\
2.38)\end{array}$ \\
\hline \multicolumn{7}{|l|}{ Comorbidities } \\
\hline \multirow[t]{2}{*}{ Diabetes mellitus, $n(\%)$} & 0 & $3(20.0)$ & $4(8.9)$ & $2(14.3)$ & 0.878 & 0.90 \\
\hline & & & & & & $\begin{array}{l}(0.23- \\
3.46)\end{array}$ \\
\hline \multirow[t]{2}{*}{ Hyperlipidaemia, $n(\%)$} & $1(25.0)$ & $4(26.7)$ & $7(15.6)$ & 0 & 0.056 & 0.31 \\
\hline & & & & & & $\begin{array}{l}(0.09- \\
1.03)\end{array}$ \\
\hline \multicolumn{7}{|c|}{ Laboratory test values before administration } \\
\hline \multirow{2}{*}{$\begin{array}{l}\text { Serum creatinine, } m g / d L, \\
\text { median (range) }\end{array}$} & 0.62 & 0.62 & 0.68 & 0.58 & 0.541 & 0.49 \\
\hline & $\begin{array}{l}(0.57- \\
0.65)\end{array}$ & $\begin{array}{l}(0.41- \\
1.19)\end{array}$ & $\begin{array}{l}(0.38- \\
1.37)\end{array}$ & $\begin{array}{l}(0.36- \\
0.8)\end{array}$ & & $\begin{array}{l}(0.05- \\
4.93)\end{array}$ \\
\hline
\end{tabular}

$\mathrm{Cl}$, confidence interval; BMI, body mass index; PS, ECOG performance status; ET, Endocrine therapy $\star P<0.05$ 


\begin{tabular}{|c|c|c|c|c|c|c|}
\hline & $\begin{array}{l}\text { Grade } 1 \\
(n=4)\end{array}$ & $\begin{array}{l}\text { Grade } 2 \\
(n=15)\end{array}$ & $\begin{array}{l}\text { Grade } 3 \\
(n=45)\end{array}$ & $\begin{array}{l}\text { Grade } 4 \\
(n=14)\end{array}$ & $\begin{array}{l}P \\
\text { value }\end{array}$ & $\begin{array}{l}\text { Odds } \\
\text { ratio } \\
(95 \% \mathrm{Cl})\end{array}$ \\
\hline \multirow{2}{*}{$\begin{array}{l}\text { Creatinine clearance, } \mathrm{mL} / \mathrm{min} \text {, } \\
\text { median (range) }\end{array}$} & 58.1 & 81.0 & 80.0 & 89.9 & 0.149 & 1.01 \\
\hline & $\begin{array}{l}(37.3- \\
92.3)\end{array}$ & $\begin{array}{l}(34.2- \\
118.9)\end{array}$ & $\begin{array}{l}(26.9- \\
188.4)\end{array}$ & $\begin{array}{l}(33.9- \\
128.1)\end{array}$ & & $\begin{array}{l}(1.00- \\
1.03)\end{array}$ \\
\hline \multirow[t]{2}{*}{ Albumin, $g / d L$, median (range) } & 3.9 & 3.9 & 4.0 & 3.9 & 0.908 & 1.06 \\
\hline & $\begin{array}{l}(3.4- \\
4.2)\end{array}$ & $\begin{array}{l}(3.3- \\
4.8)\end{array}$ & $(2.3-4.8)$ & $(2.9-5)$ & & $\begin{array}{l}(0.40- \\
2.79)\end{array}$ \\
\hline \multirow{2}{*}{$\begin{array}{l}\text { Alanine aminotransferase, } U / L \text {, } \\
\text { median (range) }\end{array}$} & 14.5 & 19 & 16 & 20 & 0.504 & 1.01 \\
\hline & $\begin{array}{l}(13- \\
20)\end{array}$ & $(8-62)$ & $(6-142)$ & $(6-106)$ & & $\begin{array}{l}(0.99- \\
1.03)\end{array}$ \\
\hline \multirow[t]{2}{*}{ Total bilirubin, $m g / d L$} & 0.72 & 0.49 & 0.72 & 0.74 & 0.117 & 2.92 \\
\hline & $\begin{array}{l}(0.45- \\
1.11)\end{array}$ & $\begin{array}{l}(0.38- \\
0.81)\end{array}$ & $(0.27-2.2)$ & $\begin{array}{l}(0.36- \\
1.27)\end{array}$ & & $\begin{array}{l}(0.76- \\
11.1)\end{array}$ \\
\hline \multirow{2}{*}{$\begin{array}{l}\text { Neutrophils, } \cdot 10^{3} / \mu L, \text { median } \\
\text { (range) }\end{array}$} & 5.46 & 2.42 & 3.28 & 2.23 & 0.349 & 0.89 \\
\hline & $\begin{array}{l}(2.35- \\
7.53)\end{array}$ & $\begin{array}{l}(0.82- \\
5.48)\end{array}$ & $\begin{array}{l}(0.53- \\
7.41)\end{array}$ & $\begin{array}{l}(0.82- \\
9.98)\end{array}$ & & $\begin{array}{l}(0.69- \\
1.14)\end{array}$ \\
\hline \multirow{2}{*}{$\begin{array}{l}\text { Platelets, } \cdot 10^{3} / \mu L, \text { median } \\
\text { (range) }\end{array}$} & 313 & 263 & 241 & 224 & $0.037^{\star}$ & 0.994 \\
\hline & $\begin{array}{l}(223- \\
350)\end{array}$ & $\begin{array}{l}(144- \\
431)\end{array}$ & $\begin{array}{l}(116- \\
380)\end{array}$ & $\begin{array}{l}(83- \\
457)\end{array}$ & & $\begin{array}{l}(0.988- \\
0.999)\end{array}$ \\
\hline \multirow{2}{*}{$\begin{array}{l}\text { Haemoglobin, } g / d L \text {, median } \\
\text { (range) }\end{array}$} & 12.1 & 11.9 & 12.9 & 12.4 & 0.368 & 1.14 \\
\hline & $\begin{array}{l}(10.7- \\
13.9)\end{array}$ & $\begin{array}{l}(8.7- \\
14.4)\end{array}$ & $(9.0-15.6)$ & $\begin{array}{l}(9.6- \\
14.7)\end{array}$ & & $\begin{array}{l}(0.85- \\
1.53)\end{array}$ \\
\hline \multirow{2}{*}{$\begin{array}{l}\text { Number of cycles, median } \\
\text { (range) }\end{array}$} & 7.5 & 10.5 & 7 & 8.5 & 0.302 & 0.98 \\
\hline & $(1-15)$ & $(2-44)$ & $(1-37)$ & $(1-38)$ & & $\begin{array}{l}(0.94- \\
1.02)\end{array}$ \\
\hline \multicolumn{7}{|l|}{ Concomitant medications } \\
\hline \multirow[t]{2}{*}{ Statin, $n(\%)$} & $1(25)$ & $2(13.3)$ & $3(6.7)$ & 0 & 0.077 & 0.24 \\
\hline & & & & & & $\begin{array}{l}(0.05- \\
1.17)\end{array}$ \\
\hline
\end{tabular}

$\mathrm{Cl}$, confidence interval; BMI, body mass index; PS, ECOG performance status; ET, Endocrine therapy $\star P<0.05$ 


\begin{tabular}{|c|c|c|c|c|c|c|}
\hline & $\begin{array}{l}\text { Grade } 1 \\
(n=4)\end{array}$ & $\begin{array}{l}\text { Grade } 2 \\
(n=15)\end{array}$ & $\begin{array}{l}\text { Grade } 3 \\
(n=45)\end{array}$ & $\begin{array}{l}\text { Grade } 4 \\
(n=14)\end{array}$ & $\begin{array}{l}P \\
\text { value }\end{array}$ & $\begin{array}{l}\text { Odds } \\
\text { ratio } \\
(95 \% \mathrm{Cl})\end{array}$ \\
\hline Proton pump inhibitor, $n(\%)$ & 0 & $3(20.0)$ & $6(13.3)$ & 0 & 0.289 & $\begin{array}{l}0.49 \\
(0.13- \\
1.85)\end{array}$ \\
\hline \multicolumn{7}{|l|}{$\begin{array}{l}\text { Sites of metastatic disease, } n \\
(\%)\end{array}$} \\
\hline Bone, $n(\%)$ & $2(50)$ & $\begin{array}{l}10 \\
(66.7)\end{array}$ & $30(66.7)$ & $\begin{array}{l}10 \\
(71.4)\end{array}$ & 0.581 & $\begin{array}{l}1.29 \\
(0.52- \\
3.23)\end{array}$ \\
\hline Liver, $n(\%)$ & $1(25)$ & $3(20)$ & $18(40)$ & $6(42.9)$ & 0.173 & $\begin{array}{l}1.89 \\
(0.76- \\
4.75)\end{array}$ \\
\hline Lung, $n(\%)$ & $2(50)$ & $5(33.3)$ & $13(28.9)$ & $6(42.9)$ & 0.872 & $\begin{array}{l}1.08 \\
(0.43- \\
2.69)\end{array}$ \\
\hline Skin, $n(\%)$ & 0 & $1(6.7)$ & $4(8.9)$ & $1(7.1)$ & 0.774 & $\begin{array}{l}1.27 \\
(0.25- \\
6.44)\end{array}$ \\
\hline Brain, $n$ (\%) & 0 & $1(6.7)$ & $2(4.4)$ & 0 & 0.563 & $\begin{array}{l}0.52 \\
(0.06- \\
4.71)\end{array}$ \\
\hline Others, $n(\%)$ & $1(25)$ & $1(6.7)$ & $4(8.9)$ & $1(7.1)$ & 0.640 & $\begin{array}{l}0.70 \\
(0.16- \\
3.13)\end{array}$ \\
\hline $\begin{array}{l}\text { Prior lines of chemotherapy in } \\
\text { metastatic disease, median } \\
\text { (range) }\end{array}$ & $\begin{array}{l}0.5(0- \\
5)\end{array}$ & $2(0-6)$ & $2(0-8)$ & $\begin{array}{l}2(0- \\
10)\end{array}$ & 0.489 & $\begin{array}{l}1.07 \\
(0.89- \\
1.29)\end{array}$ \\
\hline $\begin{array}{l}\text { Prior lines of ET in metastatic } \\
\text { disease, median (range) }\end{array}$ & $\begin{array}{l}2.5(1- \\
4)\end{array}$ & $2(0-5)$ & $1(0-6)$ & $2(0-4)$ & 0.326 & $\begin{array}{l}0.86 \\
(0.63- \\
1.17)\end{array}$ \\
\hline \multicolumn{7}{|l|}{ Prior ET for advanced disease } \\
\hline \multicolumn{7}{|c|}{$\mathrm{Cl}$, confidence interval; BMI, body mass index; PS, ECOG performance status; ET, Endocrine therapy } \\
\hline$\star P<0.05$ & & & & & & \\
\hline
\end{tabular}




\begin{tabular}{|c|c|c|c|c|c|c|}
\hline & $\begin{array}{l}\text { Grade } 1 \\
(n=4)\end{array}$ & $\begin{array}{l}\text { Grade } 2 \\
(n=15)\end{array}$ & $\begin{array}{l}\text { Grade } 3 \\
(n=45)\end{array}$ & $\begin{array}{l}\text { Grade } 4 \\
(n=14)\end{array}$ & $\begin{array}{l}P \\
\text { value }\end{array}$ & $\begin{array}{l}\text { Odds } \\
\text { ratio } \\
(95 \% \mathrm{Cl})\end{array}$ \\
\hline Tamoxifen, $n$ (\%) & 0 & $5(33.3)$ & $18(40)$ & $3(21.4)$ & 0.968 & $\begin{array}{l}1.02 \\
(0.41- \\
2.54)\end{array}$ \\
\hline Fulvestrant, $n(\%)$ & $1(25)$ & $4(26.7)$ & $16(35.6)$ & $4(28.6)$ & 0.803 & $\begin{array}{l}1.12 \\
(0.45- \\
2.84)\end{array}$ \\
\hline Aromatase inhibitor, $n(\%)$ & $4(100)$ & 11(73.3) & $25(55.6)$ & $9(64.3)$ & 0.258 & $\begin{array}{l}0.59 \\
(0.24- \\
1.47)\end{array}$ \\
\hline \multicolumn{7}{|l|}{ Palbociclib endocrine partner } \\
\hline Aromatase inhibitor, $n$ (\%) & $4(100)$ & $4(26.7)$ & $14(31.1)$ & $7(50)$ & 0.99 & $\begin{array}{l}1.01 \\
(0.41- \\
2.45)\end{array}$ \\
\hline Fulvestrant, $n(\%)$ & 0 & $11(73.3)$ & $31(68.9)$ & $7(50)$ & 0.99 & $\begin{array}{l}0.99 \\
(0.41- \\
2.43)\end{array}$ \\
\hline $\mathrm{Cl}$, confidence interval; $\mathrm{BMI}$, & nass ind $\epsilon$ & PS, ECOG & erformanc & atus; $\mathrm{ET}, \mathrm{E}$ & docrine & erapy \\
\hline$\star P<0.05$ & & & & & & \\
\hline
\end{tabular}

Table 2

Results of multivariate ordered logistic regression analysis for variables extracted by forward selection $(n=327)$

\begin{tabular}{|lllll|}
\hline Variable & Pvalue & Odds ratio & $95 \% \mathrm{Cl}$ & \\
\cline { 5 - 6 } & & & Lower endpoint & Upper endpoint \\
\hline Statin & $0.011^{*}$ & 0.104 & 0.018 & 0.598 \\
\hline Proton pump inhibitor & 0.091 & 0.290 & 0.069 & 1.220 \\
\hline Number of cycles & 0.130 & 0.966 & 0.924 & 1.010 \\
\hline BMl & $0.037 *$ & 1.118 & 1.007 & 1.241 \\
\hline Platelets & 0.076 & 0.995 & 0.989 & 1.001 \\
\hline Cl, confidence interval; BMI, body mass index & & \\
\hline$* P<0.05$ & & & \\
\hline
\end{tabular}




\section{Discussion}

The multivariate ordered logistic regression analysis performed in this study showed that significant predictors for the development of palbociclib-induced neutropenia included use of statins and BMI. Platelet count at the start of palbociclib was not extracted as a significant variable in multivariate analysis, but the lower the platelet count at the start of palbociclib administration, the more likely neutropenia was to develop. PPI was also not extracted as a significant variable, although combined use of PPI tended to be associated with neutropenia.

When the body fat content is high, anticancer drugs reportedly dissolve in adipose tissue and excretion is thus delayed [10-13]. In this study, BMI was extracted as a significant predictor for the development of palbociclib-induced neutropenia. The ROC curve analysis revealed a BMl cut-off of $\geq 22.3 \mathrm{~kg} / \mathrm{m}^{2}$ for the group likely to develop neutropenia (Grade 4). Clinicians should pay close attention to the onset of neutropenia after palbociclib administration among patients with $\mathrm{BMI} \geq 22.3 \mathrm{~kg} / \mathrm{m}^{2}$.

As for concomitant pharmacotherapies, statin use was extracted as a significant factor in this study. Concomitant use of statins resulted in a lower risk of neutropenia. This result is consistent with the results of basic research suggesting that statins prevent leukopenia [14]. Hypercholesterolemia has been reported as a risk factor for breast cancer [15], and statins are used for patients with hypercholesterolemia. Statins have also been reported to reduce the risk of breast cancer [16]. The concomitant use of statins and palbociclib might be useful in the treatment of breast cancer, although further verification is needed.

Although not significant, concomitant use of PPIs was suggested to potentially diminish the effect of palbociclib. Previous research has reported that co-administration of PPIs was significantly related to the development of neutropenia [17]. Regarding the relationship between combined use of PPIs and the occurrence of neutropenia, an increase in gastric $\mathrm{pH}$ due to the inhibitory effects of PPIs on gastric acid secretion may reduce the absorption of palbociclib [18].

Furthermore, although not significant, low pretreatment platelet count was also suggested as a risk factor for neutropenia. This result is consistent with previous findings $[19,20]$. Clinicians thus need to know about the incidence and severity of neutropenia, especially in patients with low platelet counts before palbociclib administration.

Several limitations to the current study need to be considered. First, the retrospective nature of the study may have decreased the validity of the data obtained. Second, since this study was performed at a single institute, prospective multicentre studies are needed to confirm the results.

In conclusion, concomitant use of statins and BMI were identified as significant predictors for the development of palbociclib-induced neutropenia in breast cancer. However, our findings need to be confirmed in further studies. Nevertheless, these results may assist in developing strategies to improve the safety, efficacy, and QOL among patients receiving palbociclib. 


\section{Patients And Methods}

\section{Study Period and Participants}

This study retrospectively analysed 78 breast cancer patients who had receiving palbociclib at our hospital between January 2018 and May 2020. The Medical Ethics Review Committee of the Kyoto Prefectural University of Medicine approved this study (approval no. ERB-C-1837-1). All procedures were performed in accordance with the ethical standards of the Kyoto Prefectural University of Medicine Institutional Medical Ethics Review Committee and the 1964 Declaration of Helsinki and its later amendments. No prospective studies with human participants or animals were performed by any of the authors for this article. Given the retrospective nature of this work, the need to obtain informed consent was waived for the individual participants included in the study, in accordance with the standards of the Kyoto Prefectural University of Medicine Institutional Medical Ethics Review Committee.

\section{Extraction of Variables}

For the regression analysis of factors associated with palbociclib-induced neutropenia, variables were extracted manually from medical charts. Evaluated variables included factors that could potentially impact the development of neutropenia: demographic data (sex, age, height, weight, and BMI), Eastern Cooperative Oncology Group Performance Status (ECOG-PS), number of cycles, concomitant medications (PPIs, statins), presence of comorbidities, and laboratory test values. Creatinine clearance was estimated using the Cockcroft and Gault equation based on serum creatinine, sex, age, and weight. Clinical information was extracted before administration of the first dose of palbociclib. Concomitant medication was defined as administration of another drug for $\geq 2$ weeks at the time of evaluation. The level of palbociclib-induced neutropenia was evaluated using the National Cancer Institute's Common Toxicity Criteria for Adverse Events (NCl-CTCAE; version 5). The degree of neutropenia was evaluated at the time of onset of the most severe neutropenia for patients who developed neutropenia, and as the lowest neutrophil count level within 1 month after final palbociclib administration for patients who did not develop neutropenia.

\section{Statistical Analysis}

Independent variables were analysed for multicollinearity (correlation coefficient $|r| \geq 0.7$ ), since correlations among variables can lead to unreliable and unstable results of regression analyses. Independent variables were extracted based on the strength of the correlation with the level of palbociclibinduced neutropenia (dependent variable) or clinical significance. First, univariate ordered logistic regression analyses between outcomes and each potential independent variable were performed. Subsequently, a multivariate ordered logistic regression model was constructed by employing the forward-backward stepwise selection procedure with the resulting candidate variables. The model used a variable entry criterion of 0.15 and a variable retention criterion of 0.1 . Ordered logistic regression analysis was employed, because the level of neutropenia was evaluated by a graded scale and multiple 
factors really associated as predictors for the development of palbociclib-induced neutropenia had to be analysed concurrently. Optimal cut off thresholds were determined using ROC curve analysis.

For all statistical analyses, values of $P<0.05$ (two-tailed) were considered significant. All analyses were performed using JMP version 14.3.0 (SAS Institute, Cary, NC).

\section{Declarations}

\section{Acknowledgements}

We wish to thank all the patients and medical staff at University Hospital, Kyoto Prefectural University of Medicine who were involved in this study.

\section{Author contributions}

Y.K. concept and design, data acquisition, data analysis, data interpretation, manuscript writing; K.S. concept and design, data acquisition, data interpretation; T.I. and K.T. concept and design, data interpretation; T.T. concept and design, data acquisition, data interpretation, supervision of the manuscript. All authors read and approved the final manuscript.

\section{Competing interests}

The authors declare no competing interests.

\section{References}

1. Thein, K. Z. et al. Venous thromboembolism risk in patients with hormone receptor-positive HER2negative metastatic breast cancer treated with combined CDK 4/6 inhibitors plus endocrine therapy versus endocrine therapy alone: a systematic review and meta-analysis of randomized controlled trials. Breast Cancer Res Treat, 183, 479-487 https://doi.org/10.1007/s10549-020-05783-3 (2020).

2. Rugo, H. S. et al. Progression-free Survival Outcome Is Independent of Objective Response in Patients With Estrogen Receptor-positive, Human Epidermal Growth Factor Receptor 2-negative Advanced Breast Cancer Treated With Palbociclib Plus Letrozole Compared With Letrozole: Analysis From PALOMA-2. Clin Breast Cancer, 20, e173-e180 https://doi.org/10.1016/j.clbc.2019.08.009 (2020).

3. Diéras, V. et al. Long-term Pooled Safety Analysis of Palbociclib in Combination With Endocrine Therapy for HR+/HER2- Advanced Breast Cancer. J Nat/ Cancer Inst, 111, 419-430 https://doi.org/10.1093/jnci/djy109 (2019).

4. Turner, N. C. et al. Overall Survival with Palbociclib and Fulvestrant in Advanced Breast Cancer. $N$ Engl J Med, 379, 1926-1936 https://doi.org/10.1056/NEJMoa1810527 (2018).

5. Cristofanilli, M. et al. Predictors of prolonged benefit from palbociclib plus fulvestrant in women with endocrine-resistant hormone receptor-positive/human epidermal growth factor receptor 2-negative 
metastatic breast cancer in PALOMA-3. Eur J Cancer, 104, 21-31

https://doi.org/10.1016/j.ejca.2018.08.011 (2018).

6. Rugo, H. S. et al. Impact of palbociclib plus letrozole on patient-reported health-related quality of life: results from the PALOMA-2 trial. Ann Oncol, 29, 888-894 https://doi.org/10.1093/annonc/mdy012 (2018).

7. Verma, S. et al. Palbociclib in Combination With Fulvestrant in Women With Hormone ReceptorPositive/HER2-Negative Advanced Metastatic Breast Cancer: Detailed Safety Analysis From a Multicenter, Randomized, Placebo-Controlled, Phase III Study (PALOMA-3). Oncologist, 21, 11651175 https://doi.org/10.1634/theoncologist.2016-0097 (2016).

8. Cristofanilli, M. et al. Fulvestrant plus palbociclib versus fulvestrant plus placebo for treatment of hormone-receptor-positive, HER2-negative metastatic breast cancer that progressed on previous endocrine therapy (PALOMA-3): final analysis of the multicentre, double-blind, phase 3 randomised controlled trial. Lancet Oncol, 17, 425-439 https://doi.org/10.1016/S1470-2045(15)00613-0 (2016).

9. Messina, C. et al. CDK4/6 inhibitors in advanced hormone receptor-positive/HER2-negative breast cancer: a systematic review and meta-analysis of randomized trials. Breast Cancer Res Treat, 172, 9-21 https://doi.org/10.1007/s10549-018-4901-0 (2018).

10. Desmedt, C. et al. Differential Benefit of Adjuvant Docetaxel-Based Chemotherapy in Patients With Early Breast Cancer According to Baseline Body Mass Index. J Clin Oncol, 38, 2883-2891 https://doi.org/10.1200/JC0.19.01771 (2020).

11. Gourgue, F. et al. Tumor apelin and obesity are associated with reduced neoadjuvant chemotherapy response in a cohort of breast cancer patients. Sci Rep, 11, 9922 https://doi.org/10.1038/s41598021-89385-z (2021).

12. Karatas, F. et al. Obesity is an independent prognostic factor of decreased pathological complete response to neoadjuvant chemotherapy in breast cancer patients., 32, 237-244 https://doi.org/10.1016/j.breast.2016.05.013 (2017).

13. Iwase, T. et al. Impact of body fat distribution on neoadjuvant chemotherapy outcomes in advanced breast cancer patients. Cancer Med, 5, 41-48 https://doi.org/10.1002/cam4.571 (2016).

14. Campos, M. I., Vieira, W. D., Campos, C. N., Aarestrup, F. M. \& Aarestrup, B. J. Atorvastatin and transcaryophyllene for the prevention of leukopenia in an experimental chemotherapy model in Wistar rats. Mol Clin Oncol, 3, 825-828 https://doi.org/10.3892/mco.2015.544 (2015).

15. Chowdhury, F. A. et al. Association of hyperlipidemia with breast cancer in Bangladeshi women. Lipids Health Dis, 20, 52 https://doi.org/10.1186/s12944-021-01480-2 (2021).

16. Simigdala, N. et al. Cholesterol biosynthesis pathway as a novel mechanism of resistance to estrogen deprivation in estrogen receptor-positive breast cancer. Breast Cancer Res, 18, 58 https://doi.org/10.1186/s13058-016-0713-5 (2016).

17. Hazzan, R., Darawsha, U., Neeman, Z. \& Aviv, A. Association of proton pump inhibitor use with the development of febrile neutropenia in lymphoma patients. Expert Rev Hematol, 1-5 https://doi.org/10.1080/17474086.2021.1920011 (2021). 
18. Sun, W. et al. Impact of Acid-Reducing Agents on the Pharmacokinetics of Palbociclib, a Weak Base With pH-Dependent Solubility, With Different Food Intake Conditions. Clin Pharmacol Drug Dev, 6, 614-626 https://doi.org/10.1002/cpdd.356 (2017).

19. Saito, Y., Takekuma, Y., Kobayashi, M., Komatsu, Y. \& Sugawara, M. Detection of risk factors related to administration suspension and severe neutropenia in gemcitabine and nab-paclitaxel treatment. Support Care Cancer, 29, 3277-3285 https://doi.org/10.1007/s00520-020-05842-x (2021).

20. Ahn, S. et al. Predictive factors of poor prognosis in cancer patients with chemotherapy-induced febrile neutropenia. Support Care Cancer, 19, 1151-1158 https://doi.org/10.1007/s00520-010-09284 (2011). 